\title{
A Survey of Speech Perception Tests for Children with Hearing Loss Used in Cochlear Implant Centers in Korea
}

\author{
Young-Mee Lee ${ }^{1}$, Lee-Suk Kim ${ }^{2}$ and Sung-Wook Jeong ${ }^{2}$ \\ ${ }^{\prime}$ Department of Speech-Language Pathology, The Graduate School of Ewha Womans University, Seoul; and \\ ${ }^{2}$ Department of Otolaryngology-Head and Neck Surgery, Dong-A University College of Medicine, Busan, Korea
}

\section{국내 아동용 말지각 검사 현황}

이영미 ${ }^{1} \cdot$ 김리석 $^{2} \cdot$ 정성욱 $^{2}$

이화여자대학교 대학원 언어병리학과, ${ }^{1}$ 동아대학교 의과대학 이비인후과학교실 ${ }^{2}$

\section{Received May 4, 2010 \\ Revised July 21, 2010 \\ Accepted July 29, 2010}

Address for correspondence Lee-Suk Kim, MD

Department of Otolaryngology-

Head and Neck Surgery, Dong-A

University College of Medicine,

Dongdaesin-dong 3-ga, Seo-gu,

Busan 602-715, Korea

Tel $+82-51-240-5428$

Fax +82-51-253-0712

E-mail klsolkor@chol.com
Background and Objectives Various speech perception tests have been developed for children with hearing loss (HL) in Korea, although they are not standardized yet. This study aims to examine the actual condition of speech perception tests for children with HL in Korea.

Subjects and Method Survey questionnaires and speech perception tests for children with HL were collected from 24 cochlear implant (CI) centers between March and July 2009. The speech perception tests were classified according to target ages, speech stimulus levels, and response formats. We interviewed speech therapists who had developed monosyllabic word (MW) tests, and gathered source materials, considerations, and limitations of the MW tests. We also analyzed vocabulary familiarity and phonetic balancing of words in the most commonly used MW tests.

Results Thirty-eight kinds of speech perception tests for children with HL were collected from $24 \mathrm{CI}$ centers. Among these tests, open-set MW tests and sentence tests were used in all centers. Speech therapists responsible for developing MW tests had selected words from textbooks, storybooks, and spontaneous speech data to secure vocabulary familiarity and phonetic balancing within each list. Four commonly used MW tests revealed that vocabulary familiarity was compatible with commonly used MW in preschoolers and demonstrated a similar trend in phoneme frequencies.

Conclusion The results of this study showed that current speech perception tests for children with HL should be verified, revised, and standardized in an experimental setting.

Korean J Otorhinolaryngol-Head Neck Surg 2010;53:534-46

Key Words Hearing loss $\cdot$ Cochlear implant $\cdot$ Children $\cdot$ Speech perception test.
말지각 검사(speech perception test)는 청각장애인에 게 낱말이나 문장을 들려주고 그림이나 사물을 지적하거나 따라 말하도록 하여, 말소리의 음향적 특성을 얼마나 정확 하게 듣고 이해하는지를 평가하는 검사이다. ${ }^{1,2)}$ 또한, 말지 각 검사는 보청기나 인공와우 착용 후의 말지각 진전을 모
니터하여 보청기와 인공와우의 효과와 적합의 적절성을 평 가하고, 청각재활의 목표와 방향을 설정하는데 유용한 정보 를 제공한다. ${ }^{2,3)}$

청각장애 아동의 말지각은 생활연령 (chronological age), 청력, 보청기 및 인공와우 착용 시기와 기간, 인지, 언어 능 력 등의 다양한 요인의 영향을 받는다. 따라서 청각장애 아 동의 말지각을 정확하게 평가하기 위해서 말지각 검사는 타 
당도(validity), 신뢰도(reliability), 어휘 친숙도(vocabulary familiarity), 음성적 균형 (phonetic balancing), 발달 연령의 적절성 (developmental age appropriateness)을 갖 추고 있어야 한다. ${ }^{3-7)}$ 즉, 말지각 검사를 개발할 때는 청 각장애 아동의 연령을 고려하여 일상생활에서 친숙한 단어 중에서 회화 어음과 동일한 음성학적 분포를 지닌 낱말들 을 선정하고, 표준화 절차를 통해 타당도와 신뢰도를 검증 해야 한다. 이 과정에는 검사의 타당도를 높이기 위해서 언 어병리학, 청각학, 언어학, 음성학, 통계학, 이비인후과학 등 의 분야 전문가들이 참여하여야 한다.

다양한 말지각 검사들이 국내에서 사용되고 있으나 어휘 친숙도, 음성적 균형, 발달 연령의 적절성을 고려하여 개발 한 표준화된 말지각 검사는 없다. 또한, 인공와우이식 센터 마다 사용하고 있는 말지각 검사가 달라서 청각장애 아동 에 관한 정보를 교환하는 데 어려움이 있는 실정이다. 인공 와우이식 초기에는 청각장애 아동의 말지각 검사가 부족하 여 외국의 말지각 검사를 단순히 번역하거나 변형하여 사 용하였으며, 그 말지각 검사들을 현재까지도 사용하고 있 다.,9) 보기가 없는 조건의 단음절단어검사(open-set monosyllabic word test)는 청각장애 아동의 말소리와 단어를 결합하는 능력을 반영하고, 보청기와 인공와우로 들리는 말 소리의 음향학적 특성을 얼마나 정확하게 전달받고 처리하 는지에 대한 정보를 제공하기 때문에 말지각 평가 중에서도 매우 중요하다. ${ }^{2,9,10)}$ 단음절단어검사는 단음절어의 어휘 친 숙도가 높고 음성적 균형이 회화어음과 동일하게 제작되어 야 한다. ${ }^{6,7)}$ 하지만 현재까지 단음절단어검사를 포함한 대 부분의 국내 말지각 검사들은 청각장애 아동의 말지각에 영 향을 주는 생활연령, 청력과 같은 다양한 요인과 어휘 친숙 도, 음성적 균형, 발달 연령 (developmental age)의 적절성 이 고려되지 않았고, 표준화 절차를 통한 타당도와 신뢰도 가 검증되지 않은 문제를 가지고 있다.

본 연구에서는 인공와우이식을 시행하고 있는 국내 의료 기관에서 사용하고 있는 아동용 말지각 검사의 현황을 조사 하고, 단음절단어검사의 제작 과정과 어휘친숙도, 그리고 음 성적 균형을 중점적으로 분석하여, 향후 표준화된 말지각 검 사 개발을 위한 기초 자료를 제시하고자 한다.

\section{대상 및 방법}

\section{아동용 말지각 검사 현황 분석}

2009년 2월 인공와우이식을 시행하고 있던 총 24개의 국내 의료기관(이하 인공와우이식 센터)의 의사와 언어치료 사에게 우편으로 연구협조문과 말지각 검사 현황 조사를 위
한 설문지를 발송하여, 작성한 설문지와 사용하고 있는 말 지각 검사 도구의 사본을 2009년 3월부터 7 월 사이에 우 편으로 수거하였다.

수거된 말지각 검사는 검사 적용 연령 (영유아, 학령전기 아동, 학령기 아동), 자극 반응 양식 (평정 척도, 보기가 있는 조건, 보기가 없는 조건), 자극 단위(음소, 낱말, 구와 문장) 에 따라 분류하였다. 단음절단어검사는 각 목록에서 단음 절어가 하나라도 다르면 다른 검사로 분류하였고, 문장검 사는 번역 과정에서 동일한 문장을 다르게 번역할 수 있는 점을 감안하여 단어가 다르더라도 같은 의미로 사용되는 단어(예, ‘너' 와 ‘당신', ‘뭐야?’ 와 ‘무엇입니까?' 등) 들 은 같은 단어로 취급하여 분류하였다.

\section{단음절단어검사 분석}

보기가 없는 조건의 단음절단어검사의 출처와 제작과정 에 대해 조사를 하고, 어휘 친숙도와 음성적 균형을 비교, 분석하였다. 세 군데 이상의 센터에서 사용하는 단음절단어 검사의 제작자를 직접 방문하거나 전화, 이메일을 통해서, 검사의 제작 과정, 참고 자료, 고려사항, 제한점, 보완점에 대 한 정보를 수집하였다. 그리고 단음절단어검사 간의 어휘 친 숙도를 비교하기 위해서 Lee 등9)이 제시한 2 5세 아동의 어휘 누적 빈도 $95 \%$ 내에 속하는 고빈도 단음절어와 일치 하는 단음절어의 비율을 살펴보았다. 단음절단어검사간 음 성적 균형을 비교하기 위해서 Byun 등1ㅣㅇㅣ 사용한 단음절 어의 음소 빈도를 측정하는 자동 빈도 계수 엑셀 시트를 이 용하여, 각 단음절어의 초성, 중성, 종성의 음소 빈도를 백분 율로 산출하였다.

\section{결 과}

\section{아동용 말지각 검사 현황}

협조를 요청한 총 24 곳의 모든 인공와우이식 센터에서 작성한 설문지와 현재 사용하고 있는 말지각 검사의 사본 을 회송하였다. 평정척도(scale) 및 체크리스트 각 1종, 보 기가 있는 조건(closed-set)의 자음검사 2종, 말소리 형 태 변별검사 2 종, 단음절단어검사 2 종, 문장검사 1 종, 그 리고 보기가 없는 조건(open-set)의 모음검사 1종, 자음 검사 1 종, 단음절단어검사 11 종, 이음절단어검사 5 종, 문 장검사 11 종으로, 모두 38 종의 말지각 검사 도구가 수거 되었다.

인공와우이식 센터에서는 평정척도, 체크리스트, 보기가 있는 조건과 보기가 없는 조건의 말지각 검사를 사용하여 청각장애 아동의 말지각을 평가하고 있었다(Table 1). 영 
유아의 청각적 수행력 및 말지각을 평가하기 위해서 평정 척도인 Categories of Auditory Performance(CAP)와 체 크리스트인 Infant-Toddler Meaningful Auditory Integration Scale(IT-MAIS) 을 각각 전체 센터의 $88 \%, 96 \%$ 에서 사용하고 있었으며, 보기가 있는 조건이나 보기가 없 는 조건의 말지각 검사를 사용하고 있는 센터는 없었다. 반면 학령 전 아동의 말지각 평가를 위해서는 대부분의 센 터에서 평정척도, 보기가 있는 조건과 보기가 없는 조건의 말지각 검사 등의 다양한 검사를 사용하고 있었다. 보기가 있는 조건의 말지각 검사는 단음절단어검사 $(88 \%)$, 문장검 사 $(63 \%)$, 음절형태변별검사 $(63 \%)$, 자음검사 $(42 \%)$ 의 순 으로 사용하고 있었다. 보기가 없는 조건의 말지각 검사에 서는 단음절단어검사 $(100 \%)$, 문장검사 $(100 \%)$, 자음검사 $(83 \%)$, 이음절단어검사(83\%), 모음검사 $(79 \%)$ 순으로 사 용하고 있었다. 학령기 아동용 말지각 검사를 사용하고 있 는 센터는 세 곳뿐이었으며, $\mathrm{CAP}$, 보기가 없는 조건의 단음 절단어검사와 문장검사를 사용하고 있었다(Table 1).

인공와우이식 센터별로 사용하고 있는 말지각 검사의 종 류에는 차이가 있었으나, 보기가 없는 조건의 단음절단어검 사와 문장검사는 모든 인공와우이식 센터에서 사용하고 있 었다. 아동용 단음절단어검사는 총 11 종이었으며, 그 중 8 종은 학령 전 아동용이고 3 종은 학령기 아동용으로 개발된 것이었다. 학령 전 아동용 단음절단어검사는 Evaluation of Auditory Response to Speech-Korean version(EARSK) 단음절단어검사를 11 개 센터 $(45 \%)$ 에서 사용하고 있 었으며, 그 다음으로 $\mathrm{A}, \mathrm{B}, \mathrm{C}$ 단음절단어검사를 각각 3 개
(13\%) 센터에서 사용하고 있었다(Table 2). 그 외 4종의 학령 전 아동용 단음절단어검사를 각각 1 개 센터에서 사 용하고 있었다. 학령기 아동용 단음절단어검사는 모두 3 종 으로, 각각 1 개 센터(4\%)에서 사용하고 있었다. 아동용 문 장검사는 총 11 종을 사용하고 있었으며, 그 중 8종은 학령 전 아동용이고 3 종은 학령기 아동용으로 개발된 것이었다. 학령 전 아동용 문장검사에서 많이 사용하고 있는 검사는 EARS-K의 Glendonald Auditory Screening Procedure (GASP) 문장검사와 Language-Specific Open-set 문장 검사였으며, 각각 전체 센터의 $50 \%, 45 \%$ 에서 사용하고 있 었다. 그 다음으로는 $\mathrm{A}, \mathrm{B}$ 문장검사를 각각 3 개(13\%) 센 터에서 사용하고 있었다. 그 외 4종의 학령 전 아동용 문장 검사는 각각 1 개 센터 $(4 \%)$ 에서 사용하고 있었다. 학령기 용 문장검사는 모두 3 종으로 각각 1 개 센터(4\%)에서 사용 하고 있었다(Table 2).

\section{단음절단어검사의 출처}

보기가 없는 조건의 단음절단어검사 중 $\mathrm{EARS}-\mathrm{K}, \mathrm{A}, \mathrm{B}$ $\mathrm{C}$ 단음절단어검사는 세 곳 이상의 인공와우이식 센터에서 사용하고 있었다. EARS-K 단음절단어검사의 경우, EARS 단음절단어검사의 단음절어를 번역하고, 한국어와 영어의 차이로 인해서 번역이 어려운 경우에는 동화책과 초등학교 저학년 교과서에서 발췌하여 단음절어를 추가하였다. $\mathrm{A}$ 검 사의 제작자는 학령 전 아동의 자발화를 수집하여 단음절 어를 선택하였고, $\mathrm{B}$ 와 $\mathrm{C}$ 검사의 제작자는 초등학교 교과 서, 동화책, 어휘 목록집에서 단음절어를 선택하였다. 단음

Table 1. Speech perception tests used at 24 cochlear implant centers and the number of centers using each test

\begin{tabular}{|c|c|c|c|}
\hline Target age & Condition & Tests* & No. of $\mathrm{Cl}$ centers \\
\hline \multirow{2}{*}{ Infants and toddlers } & Scale & CAP & $21(88 \%)$ \\
\hline & Checklist & IT-MAIS & $23(96 \%)$ \\
\hline \multirow{10}{*}{ Preschoolers } & Scale & CAP & $21(88 \%)$ \\
\hline & \multirow{4}{*}{ Closed-set } & Consonant test (2) & $10(42 \%)$ \\
\hline & & Speech pattern perception test (2) & $15(63 \%)$ \\
\hline & & Monosyllabic word test (2) & $21(88 \%)$ \\
\hline & & Sentence test (1) & $15(63 \%)$ \\
\hline & \multirow{5}{*}{ Open-set } & Vowel test (1) & $19(79 \%)$ \\
\hline & & Consonant test (1) & $20(83 \%)$ \\
\hline & & Monosyllabic word test (8) & $24(100 \%)$ \\
\hline & & Bisyllabic word test (5) & $20(83 \%)$ \\
\hline & & Sentence test (8) & $24(100 \%)$ \\
\hline \multirow{3}{*}{ Primary school students } & Scale & CAP & $21(88 \%)$ \\
\hline & \multirow{2}{*}{ Open-set } & Monosyllabic word test (3) & $3(12 \%)$ \\
\hline & & Sentence test (3) & $3(12 \%)$ \\
\hline
\end{tabular}


절단어검사 제작자들은 어휘 친숙도나 음성적 균형을 고려 하여 단음절어를 선택하였으나, 타당도와 신뢰도를 검증하 기 위한 표준화 절차를 거치지 않은 점을 기존 단음절단어 검사의 제한점이라고 하였다(Table 3).

Table 2. Open-set monosyllabic word tests and sentence tests for preschoolers and primary school students used at 24 cochlear implant centers and the number of centers using each test

\begin{tabular}{llc}
\hline Target age & \multicolumn{1}{c}{ Test } & No. of Cl centers \\
\hline & MW test of EARS-K & $11(45 \%)$ \\
& MW test A & $3(13 \%)$ \\
& MW test B & $3(13 \%)$ \\
Preschoolers & MW test C & $3(13 \%)$ \\
& GASP sentences of EARS-K & $12(50 \%)$ \\
& Language specific sentences & $11(45 \%)$ \\
& of EARS-K & $3(13 \%)$ \\
& Sentence test A & $3(13 \%)$ \\
\hline \multirow{4}{*}{$\begin{array}{l}\text { Primary } \\
\text { school }\end{array}$} & Sentence test B & $1(4 \%)$ \\
& MW test D & $1(4 \%)$ \\
& MW test E & $1(4 \%)$ \\
\hline St: & Sentence test C & $1(4 \%)$ \\
& Sentence test D & $1(4 \%)$ \\
\hline
\end{tabular}

Cl: cochlear implant, MW: monosyllabic word, EARS-K: Evaluation of Auditory Responses to Speech-Korean version, GASP: Glendonald Auditory Screening Procedure

\section{단음절단어검사간 어휘 친숙도와 음성적 균형 비교}

보기가 없는 조건의 EARS-K, A, B, C 단음절단어검사 의 단음절어를 2 5세 아동의 어휘 누적 빈도 $95 \%$ 내에 속 하는 고빈도 단음절어(Table 4)와 비교하여 일치도를 살 펴보았다. $\mathrm{EARS}-\mathrm{K}$ 검사의 단음절어와 일치하는 비율은 50 60\% 였고, A, B, C 단음절단어검사의 단음절어와 일치 하는 비율은 75 100\%였다(Table 5).

EARS-K, A, B, C 단음절단어검사의 초성, 중성, 종성 의 음소 분포 양상은 대체적으로 유사하였다. 초성에서는 [ㄹ], [ㅁ], [비, [씨, [저, [E] 음이 적고, [ㅂ], [ㅅ],

Table 5. The incidence of monosyllabic words matched with commonly used words by preschoolers ${ }^{9)}$ on four representative monosyllabic word tests

\begin{tabular}{lcc}
\hline \multicolumn{1}{c}{ Test } & List & No. of matched words* \\
\hline \multirow{2}{*}{ MW test of EARS-K } & List 1 & $5(50 \%)$ \\
& List 2 & $6(60 \%)$ \\
\hline \multirow{3}{*}{ MW test A } & List 1 & $17(85 \%)$ \\
& List 2 & $15(75 \%)$ \\
& List 3 & $19(95 \%)$ \\
\hline \multirow{2}{*}{ MW test B } & List 1 & $24(96 \%)$ \\
\hline MW test C & List 2 & $20(80 \%)$ \\
\hline
\end{tabular}

*matched words are the same as monosyllabic words below the $95^{\text {th }}$ percentile by cumulative frequency as seen in the Table 4 . MW: monosyllabic word, EARS-K: Evaluation of Auditory Responses to Speech-Korean version

Table 3. Summary of the source materials, limitations, and considerations for four representative monosyllabic word tests developed by speech therapists

\begin{tabular}{|c|c|c|c|c|}
\hline \multirow{2}{*}{ Item } & \multicolumn{4}{|c|}{ Monosyllabic word tests } \\
\hline & MW test of EARS-K & $M W$ test $A$ & $M W$ test $B$ & MW test C \\
\hline $\begin{array}{l}\text { Development } \\
\text { process }\end{array}$ & Self-developed & Self-developed & Self-developed & Self-developed \\
\hline Developer & Doctor, speech therapist & Speech therapist & Speech therapist & Speech therapist \\
\hline Source material & $\begin{array}{l}\text { EARS, } \\
\text { Storybooks, } \\
\text { elementary textbooks }\end{array}$ & $\begin{array}{l}\text { Spontaneous speech data } \\
\text { of preschoolers }\end{array}$ & $\begin{array}{l}\text { Vocabulary lists of normally } \\
\text { developing children aged } 5\end{array}$ & Elementary textbooks \\
\hline Consideration & Vocabulary familiarity & $\begin{array}{l}\text { Phonetic balance, } \\
\text { vocabulary familiarity }\end{array}$ & Vocabulary familiarity & Vocabulary familiarity \\
\hline Limitation & Nonstandardization & Nonstandardization & Nonstandardization & Nonstandardization \\
\hline Prerequisite & Standardization & Standardization & Standardization & Standardization \\
\hline
\end{tabular}

MW: monosyllabic word, EARS-K: Evaluation of Auditory Responses to Speech-Korean version

Table 4. Commonly used monosyllabic words collected from normally developing preschoolers aged from 2 to $5^{9)}$

\begin{tabular}{|c|c|}
\hline Cumulative frequency & Monosyllabic words (Korean) \\
\hline $25 \%$ (frequently used) & 이 입 일 다 닭 달 담 간 감 강 집 나 남 낮 날 아 안 알 앞 만 맛 말 금 곳 곰 공 \\
\hline $50 \%$ & 자 잣 잠 잘 장 한 합 선 시 신 십 실 적 전 젖 점 술 숲사 산 삼 삽 살 상 몇 명 등 들 옆 열 \\
\hline $75 \%$ & 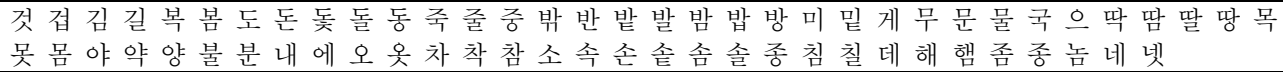 \\
\hline $95 \%$ & 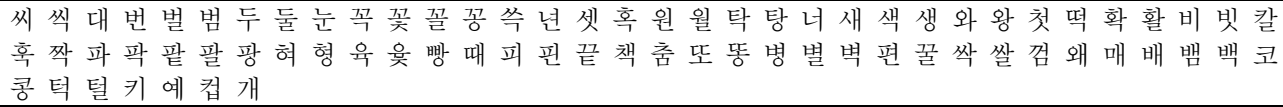 \\
\hline $100 \%$ & 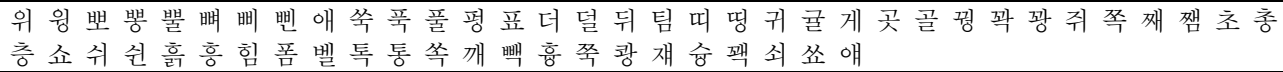 \\
\hline
\end{tabular}


[ㅈ], [ㅊ], [ㄱ] 음이 많이 분포하고 있었다. $\mathrm{EARS}-\mathrm{K}$ 단 음절단어검사의 초성에는 [ㄱ], [ᄃ], [ㅅ], [ᄌ] , [ㅎ] 음이 다른 음소에 비해서 많이 분포되어 있었으며, C 단음절단어 검사의 초성에는 [ㄱ], [ㄴ], [ㄷ], [ㅂ], [비], [시, [ㅇ] (음 가 없는 초성), [ㅈ], [ㅊ], [ㅋ] 음만 분포되어 있었다(Fig. 1). 중성에서는 [], [ㄱ], [T], [ I] 음이(Fig. 2), 종성에 서는 [ㄱ, [ㄴ], [ㄹ] 음이 많이 분포하고 있었다(Fig. 3).

\section{고 찰}

국내 총 24 개의 인공와우이식 센터에서는 평정척도, 체
크리스트, 보기가 있는 조건과 보기가 없는 조건의 말지각 검사를 사용하여 청각장애 아동의 말지각을 평가하고 있었 다. 보기가 없는 조건의 단음절단어검사와 문장검사는 모 든 센터에서 사용하고 있었으며, 보기가 있는 조건의 자음검 사, 말소리 형태변별검사, 단음절단어검사, 문장검사는 일 부 센터에서만 사용하고 있었다. 이는 보기가 없는 조건의 단음절단어검사와 문장검사가 다른 말지각 검사에 비해서 검사 소요 시간이 짧고, 청각장애 아동의 일상생활에서의 말지각에 대해 많은 정보를 제공해주며, 검사 결과를 통하 여 아동의 말-언어 발달을 예측하는 데도 도움이 되기 때 문으로 보여진다. ${ }^{2,9,10)}$
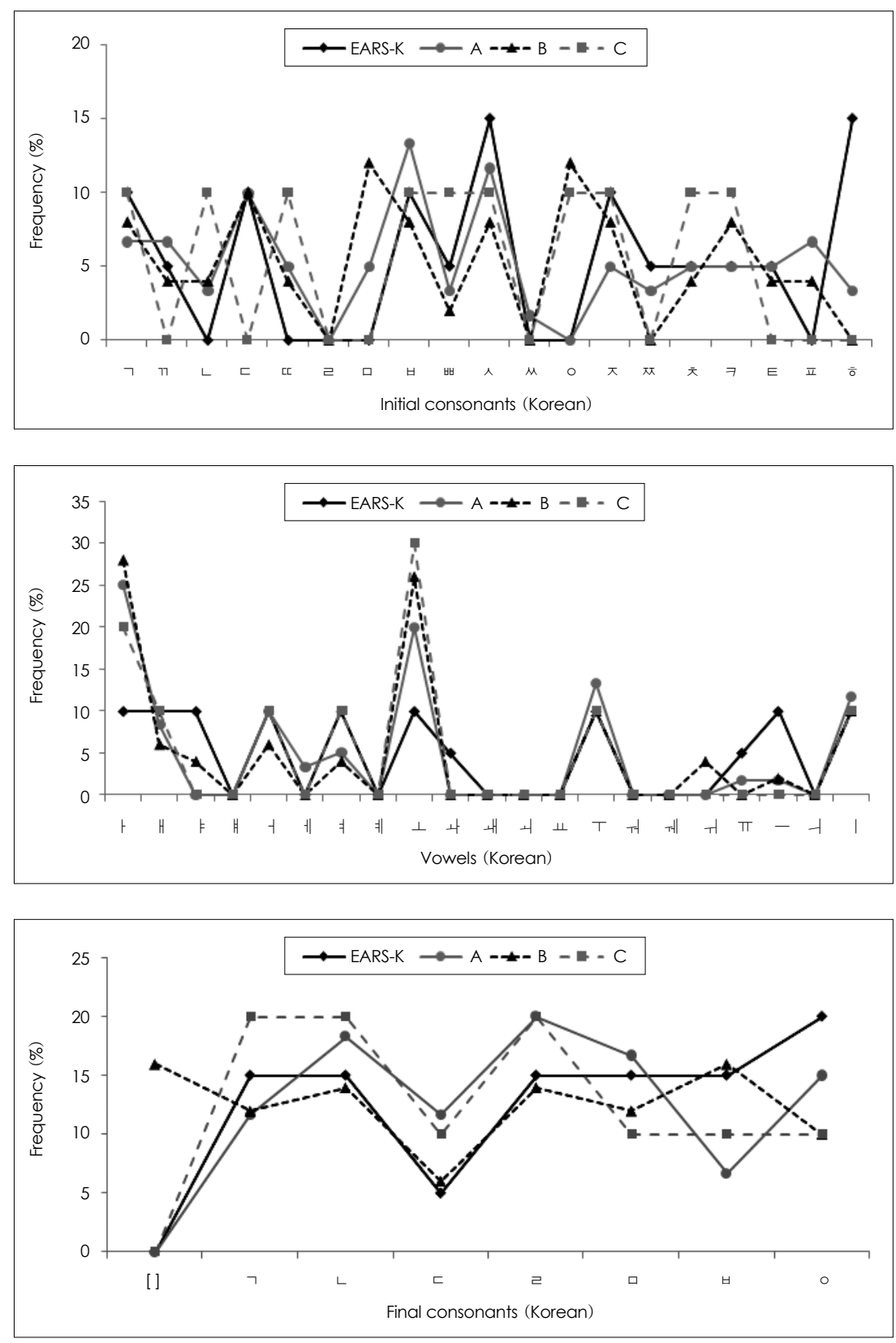

Fig. 1. Frequencies of initial consonants in the four representative monosyllabic word tests. EARS-K: Evaluation of Auditory Responses to Speech-Korean version.

Fig. 2. Frequencies of vowels in the four representative monosyllabic word tests. EARS-K: Evaluation of Auditory Responses to Speech-Korean version.

Fig. 3. Frequencies of final consonants in the four representative monosyllabic word tests. EARS-K: Evaluation of Auditory Responses to Speech-Korean version. 
말지각은 생활연령과 직접적인 연관이 있기 때문에 청각 장애 아동의 말지각을 정확하게 평가하기 위해서는 연령별 로 세분화된 검사 도구가 필요하다. ${ }^{3.5)}$ 학령 전 아동을 평가 하기 위한 말지각 검사는 평정척도, 보기가 있는 조건과 보 기가 없는 조건의 검사 등이 다양하게 갖추어져 있지만, 해 당 연령에 적절한 내용으로 구성되어 있는지에 대한 검증이 이루어지지 않은 상태이다. ${ }^{3.5)}$ 또한, 영유아의 청각적 수행 력을 직접 평가할 수 있는 검사와 학령기 아동의 언어 능력 을 고려하여 개발된 다양한 종류의 말지각 검사가 갖춰져 있지 않은 상태이다. 즉, 영유아의 청각적 수행력을 평가하 기 위해서는 CAP과 IT-MAIS만을 사용하여 평가하고, 학 령기 아동의 말지각을 평가하기 위해서는 CAP, 보기가 없 는 조건의 단음절단어검사와 문장검사만을 사용할 수 있다. 보기가 없는 조건의 학령기 아동용 단음절단어검사와 문장 검사를 사용하고 있는 센터는 전체 센터의 $12 \%$ 에 불과하 며, 나머지 $88 \%$ 의 센터에서는 학령 전 아동용 검사를 사용 하여 학령기 아동을 평가하고 있었다. 이러한 이유로 학령 기 청각장애 아동의 말지각 능력이 과대 평가되기도 하며, 조기에 인공와우이식을 받고 학령기에 접어든 아동의 단음 절단어검사와 문장검사 점수에서 천정효과(ceiling effect) 가 나타나서 교육 방향과 목표 설정에 대한 적절한 가이드 라인을 부모에게 제시하기 힘든 상황이 초래되고 있다. ${ }^{12)}$ 그러므로 영유아기부터 학령기에 이르기까지 검사 적용 연 령을 고려한 평정 척도 및 체크리스트, 단음절단어검사, 문 장검사 등을 개발하여야 한다. ${ }^{13)}$

학령 전 아동용과 학령기 아동용을 구분하여 보기가 없는 조건의 단음절단어검사와 문장검사를 개발해야 하는지에 대해서는 그 근거를 잘 살펴보아야 한다. 미국의 아동용 단 음절단어검사들을 살펴보았을 때, 학령 전 아동용 단음절단 어검사는 보기가 있는 조건으로 개발된 것이 대부분이었으 며, 보기가 없는 조건의 단음절단어검사는 학령 전과 학령 기와 같은 생활연령보다는 검사 목록의 난이도를 기준으로 하여 개발되어 있었다. ${ }^{14,15)}$ 반면에, 미국의 보기가 없는 조 건의 아동용 문장검사들은 학령 전(4 6세), 학령기(6 12 세), 청소년기(13세 이상) 와 같이 생활연령을 구분하여 개 발된 경우가 대부분이었다. ${ }^{14)}$ Jerger 등 ${ }^{16)}$ 의 연구에서 3 10 세 정상 청력 아동 87 명을 대상으로 생활연령, 어휘력, 수용언어능력(receptive language ability)에 따라 단어검 사와 문장검사 점수에 차이가 있는지 살펴본 결과, 문장검 사 점수에서만 유의한 차이가 있었다. Lee 등이이 2 6세 정상 청력 아동 138 명을 대상으로 학령 전 아동용 단음절 단어검사를 실시한 결과, 2 세 아동의 점수는 $93 \%, 3$ 세는 $93.5 \%, 4$ 세는 $98.08 \%, 5$ 세는 $98.57 \%, 6$ 세는 $99.12 \%$ 로
나타나서, 4 6세 아동의 단음절단어검사 점수는 연령에 따른 차이가 미미하였다. 단어검사에서 연령에 따른 점수 차이가 나타나지 않는 이유는 4 6세 이전 아동의 말지각은 언어 연령(language age)과 어휘력에 따른 어휘 친숙도의 영향을 받지만, 4 6세 이후에는 어휘 친숙도가 말지각에 거의 영향을 주지 않으므로 연령에 따른 점수 차이가 나타 나지 않는 것으로 보여진다. ${ }^{17)}$ 반면, 문장검사는 문장의 단 어 수, 문장 형태, 구문 복잡성, 어휘 수준 등의 다양한 요 인에 의해서 문장의 난이도가 결정될 수 있기 때문에, 문장 검사 점수는 아동의 연령, 어휘력, 수용언어능력에 따라서 차이가 나타날 수 있다. 그러므로 보기가 없는 조건의 아동 용 단음절단어검사는 생활연령보다는 난이도를 기준으로 하 여 개발하고, 보기가 없는 조건의 문장검사는 생활연령을 기 준으로 개발하는 것이 적절하겠다. 또한, 개발한 보기가 없 는 조건의 아동용 단음절단어검사와 문장검사를 정상 청력 아동에게 실시하여, 난이도와 생활연령에 따른 말지각 특 성이 잘 반영되어 있는지를 검증해야 할 것이다.

단음절단어검사의 출처 조사에서 단음절단어검사 제작자 들은 일상생활에서의 듣기 능력을 최대한 반영하고자 어휘 친숙도와 음성적 균형을 고려하였다. 이상적인 단음절단어 검사는 검사에 사용되는 단음절어가 일상 생활에 친숙하고, 표의 난이도가 균등하며, 검사의 음소 비율이 회화 어음과 유사하면서 목록마다 동일한 비율로 구성되어야 한다. ${ }^{6,7)}$ 세 곳 이상의 센터에서 사용하는 보기가 없는 조건의 단음절단 어검사 4종의 단음절어와 2 5세 아동의 고빈도 단음절어 를 비교하였을 때, $\mathrm{EARS}-\mathrm{K}$ 의 단음절어와 고빈도 단음절 어의 일치율은 50 60\%로 낮았고, 나머지 세 검사의 일치 율은 75 100\%로 비교적 높게 나타났다. EARS-K의 단 음절단어검사 제작 시 교과서, 동화책과 같은 문어(written language) 자료와 EARS의 단음절단어검사를 참고하여 단 음절어를 선택하였기 때문에, 2 5세 아동의 회화에서의 고 빈도 단음절어와의 일치율이 낮았던 것으로 생각된다. 향 후 $\mathrm{EARS}-\mathrm{K}$ 의 단음절단어검사는 고빈도 단음절어를 추가 하여 개정할 필요가 있는 것으로 생각된다.

국내 학령 전 아동의 회화음에서의 음성적 균형에 대한 자 료가 없어서 어떤 단음절단어검사가 적절한 음성적 균형을 갖추고 있는지에 대한 평가는 할 수 없었지만, 단음절단어 검사간 음소 분포의 비교를 통해서 음성적 균형에서 어떤 차이가 있는지를 살펴볼 수 있었다. 단음절단어검사 4 종의 음성적 균형을 비교한 결과, 초성, 중성, 종성의 음소 분포 양상은 대체적으로 유사하였다. 하지만 $\mathrm{EARS}-\mathrm{K}$ 와 $\mathrm{C}$ 단 음절단어검사가 다른 검사에 비해서 초성에서 일부 음소들 이 편중되어 나타나는 경향을 보였다. 이러한 경향은 $\mathrm{A}$ 와 
$\mathrm{B}$ 단음절단어검사의 단음절어 수가 각각 20 개, 25 개지만 $\mathrm{EARS}-\mathrm{K}$ 와 C 단음절단어검사의 단음절어 수는 10 개에 불과하여 특정 음소 비율이 높거나 낮게 분포된 것으로 보 여진다. 그러므로 학령 전 아동의 회화음에서의 음성적 균 형에 대한 연구를 바탕으로 기존 단음절단어검사의 단음절 어를 추가하거나 제거하여 음성적 균형을 보완해야 할 것 이며, 이때 $\mathrm{EARS}-\mathrm{K}$ 와 C 단음절단어검사의 목록에 적절 한 단음절어를 추가하여 음성적 균형을 보완하는 작업이 이 루어져야 할 것이다.

어휘 친숙도는 언어 발달에 민감한 3 4세 아동의 말지 각에 영향을 주고 음성적 균형은 일상 회화음에서의 음소 비율을 반영하여 말지각에 영향을 주므로, 단음절단어검사 제작자들은 어휘 친숙도와 음성적 균형을 중요하게 고려하 여 검사를 개발한다. ${ }^{6,17)}$ 세 곳 이상의 센터에서 사용하는 단 음절단어검사는 어휘 친숙도와 음성적 균형을 고려하여 제 작되었지만, 제작 당시 참고한 자료가 불명확하고 일정한 기 준없이 임의로 설정되어 있었다. Carhart는 미국에서 말지 각 검사 도구를 개발할 당시 phonetically balanced word 가 영어 회화음에서의 음소 비율이 아닌 영어의 모든 음소 를 조합하는데 초점을 맞추어 제작된 점과 검사내 단어가 친 숙하지 못한 점을 문제로 지적하면서, 사용 중인 말지각 검 사가 표준화 절차를 완전히 거치지 않아서 타당도가 부족 한 점을 검사자가 유념하여 검사를 실시하고 해석해야 한 다고 언급하였다. ${ }^{18)}$ 그 후 미국에서 말지각 검사를 보완하 거나 개발할 때, 회화음을 기초로 음성적 균형을 맞추고 어 휘 친숙도를 보완하는 작업을 꾸준히 하였고, 1980년대에 는 제작한 말지각 검사를 정상 청력 아동에게 실시하여 문 제점을 파악하고 보완하는 작업을 지속하였다. ${ }^{15,19)}$ 향후 국 내 말지각 검사를 보완하거나 개발하기 위해서는 미국에서 말지각 검사의 타당도를 높이기 위해서 시행한 절차와 유 사한 과정이 필요할 것으로 생각된다. 향후 정상청력 아동 의 일상생활에서의 발화를 수집하여 어휘 친숙도와 음성적 균형을 분석하고, 그 결과를 근거로 기존 검사를 수정하거 나 새로운 단음절단어검사를 제작해야 할 것이다. 또한 수 정하거나 새로 개발된 단음절단어검사를 정상 청력 아동과 청각장애 아동에게 실시하여 신뢰도와 타당도를 검증하는 표준화 작업을 해나가야 할 것이다.

국내 아동용 말지각 검사 현황 조사에서 모든 센터에서 사용하고 있는 보기가 없는 단음절단어검사를 중심으로 기 존 검사의 특성, 제한점 및 보완점을 살펴보았다. 완전히 새 로운 말지각 검사 도구를 개발하는 것은 개발과 보급에 많 은 시간과 노력이 필요한 어려운 작업이다. 따라서, 기존 검사의 단음절어를 최대한 활용하여 어휘 친숙도와 음성적
균형을 회화음과 유사하게 조정하고, 표준화 절차를 통해 타당도와 신뢰도를 갖추어서 사용하는 것이 합리적인 선택 이 될 수 있을 것이다.

이상에서 기존 말지각 검사들은 발달 연령의 적절성, 타 당도 및 신뢰도가 검증되지 않았고, 영유아와 학령기 청각 장애 아동의 말지각 평가를 위한 검사가 다양하게 갖춰지 지 않은 문제를 가지고 있다. 국내 아동용 말지각 검사들이 이러한 제한점을 가지고 있으므로, 청각장애 아동을 평가하 는 언어치료사는 현재 사용하고 있는 검사의 특성, 제한점 및 보완점을 유념하여 검사를 실시하고 해석해야 할 것이 다. 또한, 아동용 말지각 검사들은 본 연구에서 발견된 여 러 문제점을 보완하거나, 타당도와 신뢰도를 검증한 새로 운 말지각 검사를 개발하여 사용하여야 한다.

\section{Acknowledgments}

The authors thank speech therapists and doctors from 24 cochlear implant centers for their help with data collection. This study was supported by research funds from Dong-A University.

\section{REFERENCES}

1) Kirk KI, Pisoni DB, Osberger MJ. Lexical effects on spoken word recognition by pediatric cochlear implant users. Ear Hear 1995;16(5): 470-81.

2) Kim LS, Lee MY, Huh MJ, Oh YJ. Open-set speech perception development in children with cochlear implants. Korean J OtolaryngolHead Neck Surg 2004;47 (1) :15-21.

3) Bahng JH, Lee JH, Hong BN, Kim JS. A study on the development of word recognition test by pictures. Korean J Audiol 2005;9 (2):133-42.

4) Oh JJ, Kim JS, Lee JH. Development of the lists of phonetically-balanced one-syllable words for pediatric word recognition test. Korean J Audiol 2005;9 (2):161-6.

5) Wang NY, Eisenberg LS, Johnson KC, Fink NE, Tobey EA, Quittner AL, et al. Tracking development of speech recognition: longitudinal data from hierarchical assessments in the childhood development after cochlear implantation study. Otol Neurotol 2008;29(2) :240-5.

6) Osberger MJ, Miyamoto RT, Zimmerman-Phillips S, Kemink JL, Stroer BS, Firszt JB. Independent evaluation of the speech perception abilities of children with the Nucleus 22-channel cochlear implant system. Ear Hear 1991;12 Suppl 4:66-80.

7) Byun SW, Oh SH, Chae SW, Park SN, Shim YJ, Cho KK. Compromises between the frequencies of the colloquial phonemes and those of a new monosyllabic words list in Korea. Korean J OtorhinolaryngolHead Neck Surg 2007;50 (7):573-8.

8) Kim LS, Kim SJ. Cochlear implant (Re) Habilitation. Korean J Audiol 1997;1 (1):33-47.

9) Lee MY, Shin JC, Kim HH, Kim LS. Open-set monosyllabic speech perception test for preschool children. Korean J OtorhinolaryngolHead Neck Surg 2009;52 (4):312-21.

10) Waltzman SB, Cohen NL, Gomolin RH, Green JE, Shapiro WH, Hoffman RA, et al. Open-set speech perception in congenitally deaf children using cochlear implants. Am J Otol 1997;18 (3):342-9.

11) Byun SW, Chung SM, Kim HS, Go YM. A survey of phonetically balanced words lists used in training hospitals in Korea. Korean J Otolaryngol-Head Neck Surg 2005;48 (9) :1086-90.

12) Trait M. Using video analysis to monitor progress in young cochlear implant users. In: McCormick B, Archbold S, editors. Cochlear implants for young children. $2^{\text {nd }}$ ed. London: Whurr Publishers;2003. 
A Survey of Speech Perception Tests for Children with Hearing Loss I Lee YM, et al.

p.302-26.

13) Tharper AM. Who has time for functional auditory assessments? We all do! Volta Voices 2004;11 (7):10-2

14) Yoon MS. Speech perception tests. In: Kim LS, editor. Proceedings of the 1st Dong-A Hearing Symposium; 2004 November 27; Busan, Korea. Seoul: Joongang Publishing Company;2004. p.37-42.

15) Kirk KI. Assessing speech perception in listeners with cochlear implants: the development of the lexical neighborhood tests. Volta Rev 1998;100 (2):63-85.

16) Jerger S, Lewis S, Hawkins J, Jerger J. Pediatric speech intelligibility test. I. Generation of test materials. Int J Pediatr Otorhinolaryngol 1980;2 (3) :217-30.

17) Ellion LL, Clifton LA, Servi DG. Word frequency effects for a closedset word identification task. Audiology 1983;22 (3):229-40.

18) Carhart R. Problems in the measurement of speech discrimination. Arch Otolaryngol 1965;82 (3):253-60.

19) Bilger RC, Nuetzel JM, Rabinowitz WM, Rzeczkowski C. Standardization of a test of speech perception in noise. J Speech Hear Res $1984 ; 27(1): 32-48$. 


\section{$\square$ 부 록 $\square$}

1. Examples of four representative open-set monosyllabic word tests for preschoolers collected from 24 cochlear implant centers

\begin{tabular}{|c|c|c|}
\hline Test & List & Monosyllabic words \\
\hline \multirow{2}{*}{$\begin{array}{l}\text { MW test } \\
\text { of EARS-K }\end{array}$} & List 1 & 껌 흙귤 창 집 붓 돈 형 뺨 색 \\
\hline & List 2 & 탈 십 죽 손 쨈 별 컵 등 향 관 \\
\hline \multirow{3}{*}{ MW test $\mathrm{A}$} & List 1 & 돈 칼 책 산 꽃 뱀 빗 팔 떡 못 신 통 집 닭 감 쨈 빵 풀 밤 달 \\
\hline & List 2 & 귤 빵 신 춤 빗 눈 톱 햄 돈 쨈 컵 팔 줄 셋 병 성 끈 떡 목 쌀 \\
\hline & List 3 & 형 돌 땅 닭 밥 김 총핀 손 별 문 콩 털 눈 꽃 잠 껌 불 셋 국 \\
\hline \multirow{2}{*}{ MW test B } & List 1 & 입 뒤곰턱 칼 안 밥 책 몸 말 꽃코 파신 돈 잠 병 물 땀 약돌 개 숲낮 집 \\
\hline & List 2 & 눈 종 밤 춤목 맛 콩 끈 팔 자 실 뼈 돌 문 컵 앞 톱떡양 귀 닭 배 잎 손 공 \\
\hline MW test C & List 1 & 곰 별 눈 칼 손 빵 책 옷 떡 집 \\
\hline
\end{tabular}

MW: monosyllabic word, EARS-K: Evaluation of Auditory Responses to Speech-Korean version

2. Examples of open-set monosyllabic word tests for primary school students collected from $\mathbf{2 4}$ cochlear implant centers

\begin{tabular}{|c|c|c|}
\hline Test & List & Monosyllabic words \\
\hline \multirow{4}{*}{ MW test D } & List 1 & 집 소너 들 용귤 공 쌀 예돈 영 물 멋차 북 귀 감피 해 산 잠 셈 입 끝 비 \\
\hline & List 2 & 왕 파 닭 겁끈 햄 통 안 또낮 김 일 십 뒤 겉 무 새흙코 네 강 줄 짐 알 벼 \\
\hline & Lisł 3 & 곰육옆 혀 수양털 씨 개금 방 말 손빛 꽃 남 등논힘 사 자 떡 둘 쥐 이 \\
\hline & List 4 & 눈 앞 뼈 달 맛 미 점종약동 답서 침키 길 나 살꿈 배오은 국글 위형 \\
\hline \multirow{4}{*}{ MW test $\mathrm{E}$} & List 1 & 귀 산 들 용 감 돈 짐 물 입 셈 귤 너 끝 소해공 집코 쌀 멋 이 깨 북 차 영 \\
\hline & List 2 & 강 십 햄 끈 잠 비 추겉 매조김 닭옆 줄왕 네 흙무 뒤손일 또 상털오 \\
\hline & Lisł 3 & 곰 예 쥐 둘 앞씨 등 논 수피 꽃 자 육 침 겁 방 힘 말 떡 개 혀 칼 양 금 새 \\
\hline & List 4 & 종남 및 동 애글서 통 미 배눈활 꿈약 길 탑국달 점 초형 은 사 뼈 위 \\
\hline \multirow{2}{*}{ MW test $\mathrm{F}$} & List 1 & 입 뒤곰턱 칼 안 밥 책 몸 말 꽃코파신 돈 잠 병 물 땀 약돌 개숲낮집 \\
\hline & List 2 & 틈 상 문 색 달 땅벌돌 겁금꿈감 방손둘 떡 길 침 끝 점 별 불 칠 산 맛 \\
\hline
\end{tabular}

MW test F's list 1 for primary school students is the same as the MW test B's list 1 for preschoolers. MW: monosyllabic word 
A Survey of Speech Perception Tests for Children with Hearing Loss I Lee YM, et al.

3. Examples of representative open-set sentence tests for preschoolers collected from 24 cochlear implant centers

\begin{tabular}{|c|c|c|}
\hline Test & List & Sentences \\
\hline $\begin{array}{l}\text { GASP sentences } \\
\text { of EARS-K }\end{array}$ & List 1 & $\begin{array}{l}\text { 이름이 무엇입니까? } \\
\text { 신발 색깔은 무엇입니까? } \\
\text { 식구가 모두 몇 명입니까? } \\
\text { 인공와우(보청기)는 어디에 있습니까? } \\
\text { 생일은 언제입니까? } \\
\text { 선생님 이름은 무엇입니까? } \\
\text { 숫자 7 다음에는 무엇입니까? } \\
\text { 코끼리는 다리가 몇 개입니까? } \\
\text { 어디에 살고 있습니까? } \\
\text { 몇 살입니까? }\end{array}$ \\
\hline \multirow[t]{3}{*}{$\begin{array}{c}\text { Language specific sentences } \\
\text { of EARS-K }\end{array}$} & List 1 & $\begin{array}{l}\text { 학교에 가요. } \\
\text { 아이가 자요. } \\
\text { 밖이 어두워요. } \\
\text { 옷이 더러워요. } \\
\text { 침대가 저기 있어요. } \\
\text { 여기 트럭이 있어요. } \\
\text { 문이 열려 있어요. } \\
\text { 사슴 목이 길어요. } \\
\text { 아이들이 학교에 가요. } \\
\text { 컴퓨터가 고장이 나요. }\end{array}$ \\
\hline & List 2 & $\begin{array}{l}\text { 집에 옵니다. } \\
\text { 산이 푸르다. } \\
\text { 치마를 벗는다. } \\
\text { 시골에 갑니다. } \\
\text { 그네를 타고 있다. } \\
\text { 비디오가 재미있다. } \\
\text { 운동화를 신는다. } \\
\text { 놀이터에서 놉니다. } \\
\text { 지붕 위에 참새가 있다. } \\
\text { 내일 유치원에 갑니다. }\end{array}$ \\
\hline & List 3 & $\begin{array}{l}\text { 차를 마셔요. } \\
\text { 꽃이 폈어요. } \\
\text { 바다가 깊어요. } \\
\text { 방에 들어가요. } \\
\text { 난로가 따뜻해요. } \\
\text { 높은 하늘이 참 좋아요. } \\
\text { 의자에 빨리 앉아요. } \\
\text { 아파트가 넓어요. } \\
\text { 예쁜 시계를 샀어요. } \\
\text { 필통에 연필이 있어요. }\end{array}$ \\
\hline Sentence test $\mathrm{A}$ & List 1 & $\begin{array}{l}\text { 코끼리는 코가 길어요. } \\
\text { 파란색 바지를 입어요. } \\
\text { 불을 끄고 자요. } \\
\text { 그림을 예쁘게 그렸어요. } \\
\text { 문 쾅 닫지마. } \\
\text { 텔레비전 소리가 시끄러워요. } \\
\text { 엄마랑 버스를 탔어요. } \\
\text { 사탕 2개 주세요. } \\
\text { 너 이름이 뭐야? } \\
\text { 책 보고 놀아요. }\end{array}$ \\
\hline
\end{tabular}




\begin{tabular}{|c|c|c|}
\hline & List 2 & $\begin{array}{l}\text { 칼로 사과를 깎아요. } \\
\text { 아빠 어디 갔어요? } \\
\text { 과자 안 먹어요. } \\
\text { 나한테 공 던져. } \\
\text { 의자 밑에 넣어요. } \\
\text { 오늘은 날씨가 추워요. } \\
\text { 양말과 모자를 샀어요. } \\
\text { 아저씨는 눈이 커요. } \\
\text { 물이 너무 뜨거워요. } \\
\text { 빨간 연필 가져와. }\end{array}$ \\
\hline & List 3 & $\begin{array}{l}\text { 나는 키가 작아요. } \\
\text { 냉장고 위에 있어요. } \\
\text { 비디오 만지면 안돼요. } \\
\text { 우유 꺼내서 마셔. } \\
\text { 빵이 하나 없어졌어요. } \\
\text { 누구랑 같이 만들었니? } \\
\text { 아까 비가 왔어요. } \\
\text { 언니하고 오빠가 뛰어가요. } \\
\text { 접시에 딸기를 담아요. } \\
\text { 아침에 일어나서 세수해요. }\end{array}$ \\
\hline \multirow[t]{2}{*}{ Sentence test B } & List 1 & $\begin{array}{l}\text { 테레비 그만 보고 밥 먹어. } \\
\text { 지퍼 올려 / 뭐 골랐어. } \\
\text { 이거 너무 맛있네. } \\
\text { 테레비 그만 돌려. } \\
\text { 자, 여기 보세요. } \\
\text { 화장실 갔다 왔어? } \\
\text { 차 타고 할머니네 가자 } \\
\text { 냄새 나 / 돈이 없어 } \\
\text { 옷 옷걸이에 잘 걸어 놓으세요. } \\
\text { 화장실 같이 갈까? }\end{array}$ \\
\hline & List 2 & $\begin{array}{l}\text { 내일 만나요 / 팔 올려. } \\
\text { 하나 더 먹어. } \\
\text { 파란 바지가 어디 갔지? } \\
\text { 이제 집에 가자. } \\
\text { 와, 멋있네 / 뭐 탈거야? } \\
\text { 밥 먹을 때 장난치지마. } \\
\text { 그네 타자, 엄마가 밀어줄께. } \\
\text { 우리 샤워할까? } \\
\text { 그거 말고 이거 사. } \\
\text { 엄마가 책 읽어줄께. }\end{array}$ \\
\hline
\end{tabular}


A Survey of Speech Perception Tests for Children with Hearing Loss I Lee YM, et al.

4. Examples of open-set sentence tests for primary school students collected from 24 cochlear implant centers

\begin{tabular}{|c|c|c|}
\hline Test & List & Sentences \\
\hline \multirow[t]{4}{*}{ Sentence test $C$} & List 1 & $\begin{array}{l}\text { 편지를 읽어. } \\
\text { 오늘 날씨가 어때? } \\
\text { 의사는 환자를 치료한다. } \\
\text { 바다에서 고기를 잡았다. } \\
\text { 계단에서 빨리 뛰지 마세요. } \\
\text { 비를 맞아서 옷이 젖었어. } \\
\text { 꼬마가 노래를 부르며 춤을 춘다. } \\
\text { 운동을 하는 것이 힘들지 않다. } \\
\text { 여기 구멍이 난 노란 양말은 누구 꺼야? } \\
\text { 키가 큰 내 짝꿍은 귀엽고 예쁘다. }\end{array}$ \\
\hline & List 2 & $\begin{array}{l}\text { 불을 켜라. } \\
\text { 좋아하는 음식이 뭐야? } \\
\text { 동생이 연필을 깎는다. } \\
\text { 서점에서 책을 샀어요. } \\
\text { 동물에게 돌을 던지지 마세요. } \\
\text { 자동차가 많아서 길이 복잡해. } \\
\text { 나는 외투를 입고 장갑을 낍니다. } \\
\text { 영화를 보는 것이 즐겁지 않아요. } \\
\text { 저 가수가 부르는 노래는 너무 슬폈다. } \\
\text { 비가 오는 날이어서 우산을 쓰고 갔다. }\end{array}$ \\
\hline & List 3 & $\begin{array}{l}\text { 문을 열어. } \\
\text { 어느 학교에 다녀? } \\
\text { 엄마가 자장면을 만든다. } \\
\text { 공책에 이름을 쓰세요. } \\
\text { 복도에서 조용히 해 주세요. } \\
\text { 눈이 와서 길이 너무 위험하다. } \\
\text { 오빠가 간식을 먹으며 책을 읽는다. } \\
\text { 기차를 타는 것은 신나지 않아요. } \\
\text { 친구가 보내 준 생일카드가 예뻤다. } \\
\text { 형은 부러진 팔이 아파서 울었다. }\end{array}$ \\
\hline & List 4 & $\begin{array}{l}\text { 풍선을 불어. } \\
\text { 친구 이름이 뭐야? } \\
\text { 엄마가 전화를 받는다. } \\
\text { 동생은 놀이터에서 그네를 타요. } \\
\text { 더러운 옷을 깨끗이 뺍니다. } \\
\text { 무릎에 상처가 나서 약을 발랐다. } \\
\text { 예쁜 아기가 목욕하고 자요. } \\
\text { 고기를 먹는 것을 좋아하지 않는다. } \\
\text { 싸움을 하던 여자애들이 혼났다. } \\
\text { 새로 산 카메라를 꺼내 사진을 찍자. }\end{array}$ \\
\hline Sentence test D & List 1 & $\begin{array}{l}\text { 꼬마가 노래를 부르며 춤을 춘다. } \\
\text { 오늘 날씨가 어때? } \\
\text { 의사는 환자를 치료하다. } \\
\text { 바다에서 고기를 잡았다. } \\
\text { 꽃을 함부로 껶지 마세요. } \\
\text { 비를 맞아서 옷이 젖었어. } \\
\text { 편지를 읽어. } \\
\text { 운동을 하는 것은 힘들지 않다. } \\
\text { 키가 작은 내 친구는 귀엽고 예쁘다. } \\
\text { 새로 산 카메라가 고장이 났습니다. }\end{array}$ \\
\hline
\end{tabular}


Korean J Otorhinolaryngol-Head Neck Surg I 2010;53:534-46

\begin{tabular}{|c|c|c|}
\hline Sentence test $\mathrm{E}$ & List 1 & $\begin{array}{l}\text { 괜찮아요. } \\
\text { 몇 번에 거셨어요? } \\
\text { 잘 지냈어? } \\
\text { 빈자리 없어요? } \\
\text { 그냥 오세요. } \\
\text { 나중에 다시 걸겠습니다. } \\
\text { 안부 좀 전해주세요. } \\
\text { 모르면 가만히 있어. } \\
\text { 우리 일요일에 만나자. } \\
\text { 그러면 다시 전화할께요. } \\
\text { 내일 뭐 할거야? } \\
\text { 영희 좀 바꿔 주세요. } \\
\text { 끊지 말고 잠시만 기다려 주세요. } \\
\text { 너 숙제 다했으면 나 좀 보여줘. } \\
\text { 내일 학교 갔다 와서 뭐 할거야? }\end{array}$ \\
\hline
\end{tabular}

